\title{
Othering Each Other: Mimicry, Ambivalence and Abjection in Toni Morrison's The Bluest Eye
}

\author{
Shima Peimanfard*, Fazel Asadi Amjad \\ Faculty of Literature and Languages, Kharazmi University, Tehran, Iran
}

Corresponding Author: Shima Peimanfard*, E-mail: std_sh.peimanfard@khu.ac.ir

\section{ARTICLE INFO}

Article history

Received: January 24, 2018

Accepted: March 18, 2018

Published: July 01, 2018

Volume: 7 Issue: 4

Advance access: May 2018

Conflicts of interest: None

Funding: None

\begin{abstract}
This study examines the intersections of Post colonialism and Psychoanalysis in Toni Morrison's The Bluest Eye. It also aims to challenge Bhabha's notions of mimicry and ambivalence as he deems them to be great forms of resistance against White supremacy. Indeed, The Bluest Eye considers Bhabha's notion of mimicry as an oppressive strategy, especially when adopted by colonized characters like Pecola in their futile attempts to imbibe the imposed images of white culture. In addition to this literary inspiration, Julia Kristeva is among those Psychoanalytic critics who gives a further boost to my argument against Bhabha; remarking that mimicry creates the hazards of absorbing the norms of the dominant culture, and can result in psychological forms of oppression posed to the colonized, namely abjection. For instance, in Morrison's The Bluest Eye, the non-whites use mimicry as the sole arena of struggle to get out of the marsh of abjection and create a sense of self; failing to grasp that mimicry itself contains the threat of ridding them to abjection and the vicious circle of 'othering each other.' Therefore, Bhabha's ambivalent experience, to which the colonized is promoted through manifesting feats of mimicry is indeed a trap; for the voice that comes out of such experience is psychotic.
\end{abstract}

Key words: Toni Morrison, The Bluest Eye, Mimicry, Ambivalence, Abjection, Self-abhorrence

\section{INTRODUCTION}

"She was the third beer. Not the first one, which the throat receives with almost tearful gratitude; nor the second, that confirms and extends the pleasure of the first. But the third, the one you drink because it's there, because it can't hurt, and because what difference does it make?" (Morrison 91)

In his essay "Of Mimicry and Man," Bhabha launches into a discussion of the British colonialism in India, and the way it foists images of White colonizers on the colonized ones. The incursion of the British into India was helped by virtue of pretexts such as the "civilizing mission," and its goal which was to thrust an outward cloak of otherness on Indians. As Bhabha puts it, the colonial discourse has turned the colonized into "a subject of difference that is almost the same, but not quite" (86). Therefore, the colonized, consciously absorbs the "reformed" image as a mask, that is, as a means to preserve and conceal his/her inward difference from the colonizer. In that case, having adopted a reformed image without disavowing their own cultural values, the colonized succeeds in the subversion of colonial power and hence advances to topple the white gaze of colonialism. However, giving credence to mimicry as a form of resistance, Bhabha does not point to the fact that how and when mimicry desists from being subversive to the colonizer. Yet Toni Morrison and Julia Kristeva are among those authors and critics who remark that mimicry can create the hazards of absorbing the norms of the dominant culture, and thus results in psychological forms of oppression, namely delirium and abjection.

Toni Morrison's first novel, The Bluest Eye, depicts the grim world of the Breedloves, an African-American family of Lorain, Ohio, after the Great Depression. Galvanized by "the Black Is Beautiful" motto of late 1960s African-American culture, The Bluest Eye indicates how the unconscious vanity of white racism results in a blind mimicry, which causes insanity in colored people. Due to its undaunted narration of sexual discrimination, child molestation and rampant racism, there have been various attempts to block the book from libraries and schools. Nevertheless, decades after its publication, it's still regarded as a controversial book.

The Breedlove's lifetime is haunted by a series of grisly events: Parents fight constantly and their home has been reduced to ashes by the promiscuous, dipsomaniac father, Cholly. Crushed by the debris of that traumatic event, their daughter, Pecola, wishes for physical transformation: "It had occurred to Pecola some long time ago that if her eyes, those eyes that held the pictures, and knew the sights-if those eyes of hers were different, that is to say beautiful, she herself would be different" (Morrison 40). In fact, she pins the lack of love between her family members and the constant skirmishes between her parents on the shortcomings of her appearance; fantasizing, ". If she looked different, beautiful, maybe Cholly would be different, and Mrs. Breedlove too. 
Maybe they'd say, 'look at pretty-eyed Pecola. We won't do bad things in front of those pretty eyes" (40). In that case, since Pecola has always regarded beauty as identical to whiteness, she beseeches for the blue eyes of a white girl in order to change the way she is seen by others. Indeed, Pecola's unrelenting assumption of the white gaze can be incorporated into Bhabha's discourse as an instance of how and when mimicry desists from being a subversive tool, and becomes catastrophic to the mimic.

\section{MIMICRY AS A PSYCHOTIC TRAP: DESCENDING THE COLONIZED DISCOURSE}

McLeod believes that "Bhabha's 'discourse of colonialism' is characterized by both ambivalence and anxious repetition" (54). He contends:

In trying to do two things at once-construing the colonized as both similar to and the other of the colonizersit ends up doing neither properly. Although the aim is to fix knowledge about other people once and for all, this goal is always deferred. The best it can do is set in motion the anxious repetition of the colonized subject's stereotypical attributes that attempt to fix it in a stable position. But the very fact that stereotypes must be endlessly repeated reveals that this fixity is never achieved. (54)

Likewise, I believe, Bhabha's perception of the colonized promises more than it delivers. For instance, his theory of mimicry fixes the colonized as an ambivalent man. That is, subversion in Bhabh's terms is only possible as long as the colonial subject repeats and mimics the colonizer's culture in his civilizing mission. In this sense, Bhabha contends, "The menace of mimicry is its double vision which in disclosing the ambivalence of colonial discourse also disrupts its authority" (88). Thus, it requires the necessary distortion of all signs of discrimination and domination. He further mentions that mimicry "problematizes the signs of racial and cultural priority, so that the 'national' is no longer naturalizable" (87), that is to say, mimicry displays the artificiality behind the symbolic expressions of power. In that case, the mimic men are "the figures of a doubling, the part-objects of a metonymy of colonial desire which alienates the modality and normality of those dominant discourses in which they emerge as 'inappropriate' colonial subjects" (88). At this point, Bhabha wreaks havoc on Western ideology, assuming, in that case, that his postmodern tenets of colonialism are productive and ideally subversive. Yet, this paradigm brings forth a trap, keeping the colonized and the colonizer chained to each other; and hence, dooms him/her to an endless in-between space.

Moreover, Bhabha's theory raises the question of whether the colonized can maintain his/her sanity, being in an ambivalent space, "always the split screen of the self and its doubling" (156). Indeed, this essay contends that Bhabha's "borderline experience," to which the colonized is promoted through manifesting feats of mimicry, is indeed a ruse; for the voice that comes out of such experience is psychotic.

\section{ВНАВНА'S “MIMIC (WO)MAN" OR KRISTEVA'S "ABJECT SUBJECT"?}

Julia Kristeva believes, the discourse of "borderline subjects" is comprised entirely by "abjection". In her "Powers of Horror: An Essay on Abjection," she defines this feature as "what disturbs identity, system, order. What does not respect borders, positions, rules" (4), and what is "above all ambiguity" (4). This ambiguity, or in Bhabha's words, ambivalence, is what that epitomizes the colonial mimic man whom turns to "his alienated image; not self and Other but the Otherness of the self-inscribed in the perverse palimpsest of colonial identity" (44). He continues, by constructing a colonized other and accentuating "its slippage, its excess, its difference" (127) the colonized ones can collapse the notions of colonial difference that preceded them. Yet, Kristeva argues, this ambiguity results in the collapse of self-limits (5). Thus, the borderline mimic (wo)man "is neither subject nor object; neither inside, nor outside, neither here, nor there" (Peimanfard and Asadi A. 78). As Bhabha puts it, "he speaks from where it is not" (47). In fact, suffering from an ambivalent status, the mimic (wo)man resembles a borderline patient stuck in a mimetic oscillation, being concurrently the same and other. Therefore, in Bhabha's theory, the colonized can only operate under the constraints of mimicry. In other words, for the colonized to deploy some sort of resistance against the colonizer; he has to mimic, emulate, and be subject to a constant ambivalent feeling toward him/herself. Consequently, Bhabha's mimic (wo)men "will ultimately lose their tracks in semblances and masks, fighting for a life without any place of their own to live" (Peimanfard and Asadi A. 78). At this point, both Julia Kristeva and Toni Morrison are hesitant to celebrate mimicry and, more, are critical of its threats posed to the colonized. Therefore, based on Kristeva's theory, next part is going to discuss how Bhabha's mimic (wo)man is abjected to something delusive, psychotic and irreducible to language in Morrison's text.

\section{ABJECT REPRESNTATION OF MIMIC (WO)MAN IN THE BLUEST EYE}

For Pecola, the abjection of self emanates firstly from the relationship she has had with her mother, Pauline. Kristeva explains how the abject is prominently related to our primal repression; how it exposes us to "our earliest attempts to release the hold of maternal entity - thanks to autonomy of language" (13). Indeed, one has to become "homologous to another in order to become himself" (13), and then reject the maternal entity to become a subject. Yet all Pecola could firstly associate with and consequently reject was a distant mother who not only refuses to have a close relationship with her, she even ignores her presence. In a way, Pecola cannot reject her mother; since, her mother have already rejected her. Indeed, to her mother, Pecola is no more than a mnemonic repertoire of her own failed hankerings to achieve white beauty. She incorporates this anxiety of feminine identification by sighing for her unborn child as the signifier of her own fancy to become white. Yet, when Pecola is born, Pauline deems her a "Head full of hair, but Lord, she 
was ugly" (100). Therefore, disappointed by her dream of a white-like child, Pauline's psychotic reaction was to abject Pecola, for the blonde teen of her employers, the Fisher's girl. Indeed, one of the major climacteric events in Pecola's maturation occurs in the kitchen of this family. When Pecola comes by the Fishers to pick up the laundry, she touches the berry cobbler and accidentally drops it to the floor. Flustered by what her daughter has done, Pauline beats Pecola with "the back of her hand and knocks her to the floor," causing her poor girl to "slide in the pie juice," and chastising her with "words that were hotter and darker than the smoking berries" (87). Yet, she caresses the upset "pink and yellow" fisher girl with "words of honey": "Hush, baby, hush...come here. Don't cry no more" (87). Soon, Pecola finds out, it is the fisher's girl which receives the mother love that rightly belongs to her and she has no place in her mother's heart. Yet Pauline is satisfied so much with her status in the white family that she denies her own family:

More and more Pauline neglected her house, her children, her man, they were like the afterthoughts one has just before sleep,... the dark edges that made the daily life with the Fishers lighter, more delicate, more lovely.... Here she found beauty, order, cleanliness, and praise. (101)

Having been unable to pass the primal repression for what Kristeva calls "maternal anguish", Pecola is "unable to be satiated within the encompassing symbolic" (8). Consequently, Pecola is not capable of symbolizing or naming what she has lost, and the lost object remains unnamable. This can also be hinted in the way Pecola uses language: she does not profess her sense of loss to other people, and stealthily prays to God for it in her solitude. Yet, the only time when her prayer emerges in her own words was "when she petitions the quack, soaphead, for the bluest eyes; and he in guise of a false god answers it" (Simpson 42).

Being incapable of passing through the symbolic domain and availing of language, Pecola does not achieve the capacity to become a unified subject, and hence, cannot express her individuality as 'I'. In fact, what characterizes the abject person is that when she fails to reach her subjectivity through the symbolic order; she struggles to extract her existence from an all-mighty, "other". As Kristeva writes, a person experiences abjection "only if an Other has settled in place and stead of what will be her. An Other who precedes and possesses her and through such possession cause her to be" (10). In fact, since the abject finds his/her existence within the Other, he/she looks for his/her sense of loss in the Other, and pursues pseudo-objects represented by the Other. These pseudo-objects offer him/her a modicum of contentment but seizes his/her subjectivity. As Kristeva explains, "the abject is in short a stray. He is on a journey, during the night, the end of which keeps receding. He has a sense of the danger, of the loss that the pseudo-object! attracting him represents for him" (5). The pseudo-objects Pecola pursues and attempts to mimic are definitely those images that connote pure Whiteness, for she believes they will bestow her merriment. Living on the edges of American society, the African-American people are constantly bombarded by the quintessential, unattainable images of the dominant White culture. Nonwhite girls are indoctrinated to weigh themselves against the Shirley Temple paragon and find themselves lacking. The most treasured Christmas gift is a White blonde doll: "adults, older girls, shops, magazines, newspaper, window signs - all the world agreed that a blue-eyed, yellow-haired, pink-skinned doll was what every girl child treasured" (Morrison 20).

Kristeva further contends, what causes abjection is "what disturbs identity, system, order. What does not respect borders, positions, rules. The in-between, the ambiguous, the composite" (4). Pecola has been treated this way all her life; she has been derided, taunted and downgraded as something between subject/object, American/African, an ambivalent figure. This ambiguity, Kristeva continues, results in the shattering of self-limits (5). As a dark hybrid, Pecola does not even exist in an American community, and every encounter with white people limits her to the borders of abjection. When she goes to the shop of a white immigrant local grocer to buy her favorite candies, the only thing she receives is a cold silent dejection from him:

She looks up to him and sees the vacuum where curiosity ought to lodge. And something more. The total absence of human recognition-the glazed separateness. She does not know what keeps his glance suspended. Perhaps because he is grown, and a man, and she a little girl. But she has seen interest, disgust, even anger in grown male eyes. Yet this vacuum is not new to her. It has an edge; somewhere in the little lid is the distaste. She has seen it lurking in the eyes of all white people. So. The distaste must be for her, her blackness. All things in here are flux and anticipation. But her blackness is static and dread. And it is the blackness that accounts for, that creates, the vacuum edge in the eyes with distaste in white eyes. (Morrison 42)

Stumbling across such extreme denial, and more, due to the malfunction of her symbolic order, Pecola becomes incapable of communicating verbally with the grocer. Instead, she uses her finger to direct the grocer's attention to her most-liked candy, Mary Jane. In fact, Pecola's internalization of the abjection cast upon her is refigured both in her silence, and in her penchant for masquerading white psudo-objects. Her fretfulness at the grocer's nonchalance is soon replaced with her rejoicing at getting hold of the three Mary Jane candies. Since chomping on the candy, Pecola can best ingest the image of Mary Jane. As the narrator puts it, "She eats the candy, and its sweetness is good. To eat the candy is somehow to eat the eyes. Eat Mary Jane. Love Mary Jane. Be Mary Jane" (43). But there is neither sign of mimicry in her request which "marks those moments of civil disobedience within the discipline of civility: signs of spectacular resistance." (Bhabha 121), nor signs of mimicry which "represents an ironic compromise" (86). Indeed, Pecola's passionate mimicry of the white pseudo-objects is the response to both family and society's abjection, negligent of the fact that mimicry itself comprises the threat of ridding oneself to abjection and and hence forever condemns people to the vicious circle of 'othering each other'. 


\section{'OTHERING EACH OTHER': THE NON-WHITES' SELF-ABHORRENCE}

In The Bluest Eye, self-abhorrence is an internal disgust burst through the majority of non-whites. For instance, the black boys attempt to abject Pecola with a chant of "Black e mo", failing to grasp the fact that such a chant is disparaging to themselves as well. Geraldine, one of these boys' mother is another instance for Morrison's critique of a particular kind of internalized racism. Throughout the book, we see the mother's coldness toward his son Junior has caused him to become sadistic and cruel; especially, toward his mother's cat which she fondles most. Geraldine's adoration of whiteness and her abomination of "niggers" is, albeit, a kind of self-abhorrence: She teaches her son how to analyze other black people in order to distinguish the "good" ones from the "bad" ones. As the narrator mentions, "White kids; his mother did not like him to play with niggers. She had explained to him the difference between colored people and niggers. They were easily identifiable. Colored people were neat and quiet; niggers were dirty and loud" (Morrison 87). This method is not foolproof; however, since "[T] he line between colored and nigger was not always clear; subtle and telltale signs threatened to erode it, and the watch had to be constant" (87). Yet, jacketing the contours and frameworks of whiteness specified by the dominant culture, Geraldine finds solace in being labeled as "colored" not "black". In that case; since, she shudders at her own blackness, she luxuriates in making a master of herself by abjecting poor, dark-skinned ones like Pecola. Once when Junior lures Pecola into their house; he kills her mother's cat, and lays the blame on Pecola. Seeing Pecola as a pack of poverty, dirt and degradation, Geraldine slanders her as "a nasty little black bitch" (92), and kicks her out of the house, negligent of the fact that she is an Other making another of herself.

Pecola's family also injects her with their own "learned" self-disgust, internalizing the belief that all of them are abjected and otherred as ugly:

You looked at them and wondered why they were so ugly. Then you realized that it came from conviction, their conviction. It was as though some mysterious, all-knowing master had given each one a cloak of ugliness to wear, and they had each accepted it without question. The master had said, "You are ugly people. They had looked about themselves and saw nothing to contradict the statement; saw, in fact, support for it leaning at them from every billboard, every movie, every glance. "Yes," they had said. "You are right." And they took the ugliness in their hands, threw it was a mantle over them, and went about the world with it. (39)

Indeed, Pecola's mother (Pauline) was the first one in the family who devoted all her life to win the masquerade of white femininity she sees at the American picture shows and the Hollywood films. What the screen displays cryptically intensifies Pauline's ultimate frustration with herself, and with what she has. In portraying Pauline as utterly besotted with the imposed images of cinematic manifestation, she herself admits:

The onliest time I be happy seem like when I was in the picture show. Every time I got, I went. I'd go early before the show started. They'd cut off the lights and everything be black. Then the screen' $d$ light up, and I'd move right on in them pictures. White men taking such care of their women, and they all dressed up in big clean houses with the bathtubs right in the same room in the toilet. Then pictures gave me a lot of pleasure, but it made coming home hard, and looking at Cholly hard. I don't know. I remember one time I went to see Clark Gable and Jean Harlowe. I fixed my hair up like I'd seen her in magazine. A part on the side, with one little curl on my forehead. I looked just like her. Well, almost just like her. (97)

The passage above suggests, picture shows and Hollywood stars promote certain ideas of beauty, which stimulates Pauline's envy, as she sees them portrayed in both images and movies. Lacking the power to be impervious to the idealized images of monetary security, comfort, and romance she notices on the screen, Pauline strives for mimicking a white idol, and hence making a master of herself but an Other of her family. She proceeds so far in her struggle as "she was never able, after her education in the movies, to look at a face and not assign it some category in the scale of absolute beauty, and the scale was one she absorbed in full from the silver screen" (97). Nevertheless, her association with Jean Harlow did not pass muster, when due to her pregnancy, she loses a front tooth. This event, then, dashes all her hopes of attaining white elegance to the ground, saying, "There I was, five months pregnant, trying to look like Jean Harlow, and a front tooth gone. Everything went then. Look like I didn't care no more" (98).

Pauline's religious status is another form of self-abhorrence. The narrator mentions, "[S]he joined a church where shouting was frowned upon" (100). For instance, when she chews over her husband's debauchery and inebriation; she postulates herself as victim, and deems Christianity as her only source of long-sufferingness. This, also, signifies that, for Pauline, Christianity is only an excuse behind the grotesque imitation of white values, and a way to get out of the puddle of the otherness, the abject.

Moreover, her husband, Cholly, plays a great role in encouraging her to dis-identify with blackness, and put on a white masquerade, which moves her to the borders of self-abhorrence. Since, "[S]he, like a Victorian parody, learned from her husband all that was worth learning - to separate herself in body, mind, and spirit from all that suggested Africa" (167). Nonetheless, Pauline has banished his love from her heart and finally abjected her husband forever by abandoning him. The abandonment of which is not a new story, but rather an extended series of treatments Cholly has been exposed to since infancy. His mother deserted him in a junk heap on the railroad when he was only four days old; he was rescued by his great aunt jimmy, who has since continuously jogged his memory of her great services to him. Afterwards, he takes to his heels to find his father but it ends in abjection especially when his father cold-shouldered him for a crap game. Besides, Cholly's first encounter to racial assault occurred while he was having his first sexual experience with someone named Darlene. A few white men happened to ar- 
rive on the scene, and they bullied Cholly even more when they ordered him to continue what he was doing. The acerbity of their tone, their overpowering presence and their flagrantly racist remarks rendered Cholly abortive and hence, socially abjected. He became then fully cognizant of his vulnerability in the face of a belligerent white world that emasculates him both physically and spiritually. As the narrator asserts, "They were big, white, armed men. He was small, black, helpless. His subconscious knew what his conscious mind did not guess-that hating them would have consumed him, burned him up like a piece of flash coal" (119). Therefore, being not capable enough to strike back at the white intruders, he vented his wrath on Darlene as the one who "bore witness to his failure, his impotence. The one whom he had not been able to protect, to spare, to cover from the round moon glow of the flashlight" (119). After that disastrous event, he spends the next few years shifting from town to town and from woman to woman. By the time he weds Pauline, he is a vagabond of feral tastes, feeling trapped in his marriage and life.

Unquestionably, Cholly's state of self-abhorrence reflects on his impotence to overcome his family's felt deficiencies without further abjecting them. The narrator, for instance, comments:

What could a burned-out black man say to the hunched back of his daughter? If he looked into her face, he would see those haunted, loving eyes. The hauntedness would irritate him, the love would move him to fury. How dare she love him? Hadn't she any sense at all? What was he supposed to do about that? Return it? How? What could his calloused hands produce to make her smile. (127)

In fact, the father's tenderness proves calamitous for his girl when he rapes her; a repetition of his traumatic sexual denigration, but this time with him in the role of oppressor: "The clear statement of her misery was an accusation. He wanted to break her neck - but tenderly. Guilt and impotence rose in a bilious duet. What could he do for her-ever?" (161). This event can stand as the apogee of abjection in Pecola's life when Pecola ends up seeing herself outside the human contact, she feels inside the coercion of being as something tarnished, repugnant and abject. As Kristeva asserts:

The subject, weary of fruitless attempts to identify with something on the outside, finds the impossible within; when it finds that the impossible constitutes its very being, that it is none other than abject. [...], the abject is elaborated through a failure to recognize its kin; nothing is familiar, not even the shadow of memory. (5)

Therefore, Pecola's craving for love and merriment will never come true, since the only nearest people who could love her has also abjected her in their own ways. Her delirium of having the bluest eyes towards the end of the story also confirms Kristeva's argument of how the abjection of the self proves costly in exposing both family and society's culpability for malfunction of symbolic order and hence creating mad girls like Pecola. In other words, unable to fully be a part of the symbolic order, Pecola has to manifest her existence through delirium and madness. Her aspiration for physical transformation springs from the need to be accepted in a society which is particularly ill-disposed to colored people whose features do not measure up. To fulfill her aspiration, Pecola meets a pishogue, Soaphead Church, who promises her to have the bluest eyes since he is "wholly convinced that if Black people were more like White people they would be better off" (Morisson 223). Soaphead Church says:

I, I have caused a miracle. I gave here the eyes. I gave her the blue, blue, two blue eyes. Cobalt blue. A streak of it right out of your own blue heaven. No one else will see her blue eyes. But she will. And she will live happily ever after. I, I have found it meet and right to do so. (143)

With society and family's constant aggravation, Pecola's great sense of loss traps her in a mimetic oscillation which itself results in the delirium of obtaining a pair of the bluest eyes. At the end, we hear her chattering with an imaginary bosom friend about the magnificence of the bluest eyes she alone has been bestowed upon:

What? What we will talk about?

Why, your eyes.

Oh, yes, My eyes. My blue eyes. Let me look again.

See how pretty they are.

Yes, They get prettier each time I look at them....

Prettier than the sky?

Oh, yes. Much prettier than the sky.

Prettier than Alice-and-Jerry Storybook eves?

Oh, yes. Much prettier than Alice-and-Jerry Storybook eyes. (156)

\section{CONCLUSION}

Homi K. Bhabha maintains that the act of colonial mimicry is based upon ambivalence: an uncertainty of difference between the colonizer and the colonized. Thus, by constructing a colonial other and emphasizing "its slippage, its excess, its difference" (127), post-colonial authors can undermine the notions of colonial difference that preceded them. Notwithstanding this theory, such a strategy is not sustained enough to undermine the colonizer's norms. For there is so great a dichotomy between Whiteness and Otherness that the author is unable to question the authenticity of difference. Rather, in this novel, the non-whites use mimicry as the sole arena of struggle to get out of the marsh of abjection, failing to grasp that mimicry itself contains the threat of ridding people to abjection, and hence forever condemns them to the vicious circle of 'othering each other'. In that case, the condition of Bhabha's mimic (wo)man as an anomaly or abject never alters. In The Bluest Eye, Pecola's psychotic deliriums which at the end give its place to chronic dementia (abjection) are the response to her inherited self-abhorrence, albeit, fuelled by the hegemony of the dominant society and inflamed by her rape ordeal. Her delirium of gaining the bluest eye might encapsulate Bhabha's definition of the mimic as a figure that "thrives to be culturally 'seen.' What (she) aspires for is visual mediation" (85). However, in her struggle to be culturally recognized, Pecola has been masqueraded by the dominant culture and her mimicry is self-destructive rather than productive. 


\section{REFERENCES}

Bhabha, Homi K. The Location of Culture. London and New York: Routledge, 1994. Print.

---. "Of Mimicry and Man: The Ambivalence of Colonial Discourse." The Location of Culture. London: Routledge, 1994. Print.

---. "The Other Question: Difference, discrimination and the Other Discourse Discourse of Colonialism." In Theory: Marginalization and contemporary Culture. Ed. Russell Fergusson, et al. New York: The New Museum of Contemporary Art, 1990. Print.

Kristeva, Julia. Desire in Language: A Semiotic Approach to Literature and Art. New York: Columbia UP, 1980. Print.
---. Powers of Horror: An Essay on Abjection. New York: Columbia UP, 1982. Print.

McLeod, John. Beginning Postcolonialism. England: Manchester University Press, 2000. Print.

Morrison, Toni. The Bluest Eye. New York: Plume, 1994. Print.

Peimanfard, Shima and Asadi A. Fazel. "“"Mimic (Wo)man” or "Abject Subject"? Crisscrossing Glances of Postcolonial and Psychoanalytic Theories in Rhys's Wide Sargasso Sea." ALLS 9.1 (2018):75-80. Print.

Simpson, Ritashona. Black Looks \& Black Acts: The Language of Toni Morrison in The Bluest Eye and Beloved. NewYork: Peter Lang, 2007. Print. 